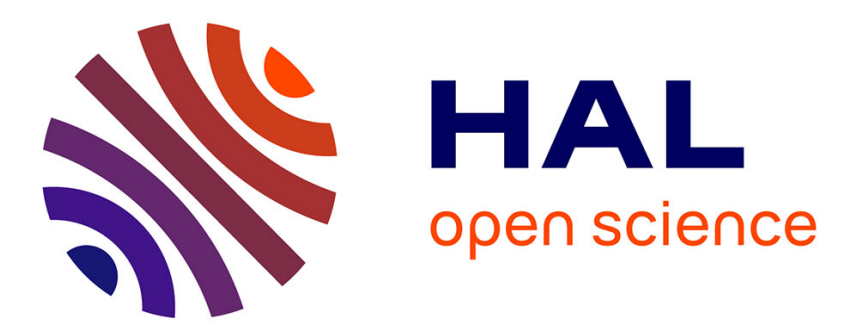

\title{
Preparation of new proton exchange membranes using sulfonated poly(ether sulfone) modified by octylamine (SPESOS)
}

Walid Mabrouk, Lionel Ogier, F. Matoussi, Cyrille Sollogoub, Serge Vidal, M. Dachraoui, J.F. Fauvarque

\section{To cite this version:}

Walid Mabrouk, Lionel Ogier, F. Matoussi, Cyrille Sollogoub, Serge Vidal, et al.. Preparation of new proton exchange membranes using sulfonated poly(ether sulfone) modified by octylamine (SPESOS). Materials Chemistry and Physics, 2011, 128 (3), pp.456-463. 10.1016/j.matchemphys.2011.03.031 . hal-02455972

\section{HAL Id: hal-02455972 \\ https://hal.science/hal-02455972}

Submitted on 27 Jan 2020

HAL is a multi-disciplinary open access archive for the deposit and dissemination of scientific research documents, whether they are published or not. The documents may come from teaching and research institutions in France or abroad, or from public or private research centers.
L'archive ouverte pluridisciplinaire HAL, est destinée au dépôt et à la diffusion de documents scientifiques de niveau recherche, publiés ou non, émanant des établissements d'enseignement et de recherche français ou étrangers, des laboratoires publics ou privés. 


\title{
Preparation of new proton exchange membranes using sulfonated poly(ether sulfone) modified by octylamine (SPESOS)
}

\author{
W. Mabrouk ${ }^{a, b, c}$, L. Ogier ${ }^{a}$, F. Matoussi ${ }^{c}$, C. Sollogoub ${ }^{b, *}$, S. Vidal ${ }^{a}$, M. Dachraoui $^{c}$, J.F. Fauvarque $^{\mathrm{b}}$ \\ a Société ERAS Labo, 222 RN 90, 38330, St Nazaire Les Eymes, Grenoble, France \\ b Laboratoire des Matériaux Industriels, Conservatoire National des Arts et Métiers de Paris 75003, Paris, France \\ ${ }^{c}$ Laboratoire de Chimie Analytique et Electrochimie, Faculté des Sciences de Tunis, Campus Universitaire 1092, Tunis, Tunisie
}

Keywords:

Polymers

Electrochemical properties

Glass transitions

Nuclear magnetic resonance (NMR)

\begin{abstract}
A B S T R A C T
Sulfonated poly(arylene ether sulfone) (SPES) has received considerable attention in membrane preparation for proton exchange membrane fuel cell (PEMFC). But such membranes are brittle and difficult to handle in operation. We investigated new membranes using SPES grafted with various degrees of octylamine. Five new materials made from sulfonated polyethersulfone sulfonamide (SPESOS) were synthetized with different grades of grafting. They were made from SPES, with initially an ionic exchange capacity (IEC) of 2.4 meq g $^{-1}\left(1.3 \mathrm{H}^{+}\right.$per monomer unit). Pristine SPES with that IEC is water swelling and becomes soluble at $80^{\circ} \mathrm{C}$, its proton conductivity is in the range of $0.1 \mathrm{~S} \mathrm{~cm}^{-1}$ at room temperature in aqueous $\mathrm{H}_{2} \mathrm{SO}_{4} 1 \mathrm{M}$, similar to that of Nafion ${ }^{\circledR}$. After grafting with various amounts of octylamine, the material is water insoluble; membranes are less brittle and show sufficient ionic conductivity. Proton transport numbers were measured close to 1 .
\end{abstract}

\section{Introduction}

Proton exchange membranes (PEM) are key components in many electrochemical processes: electro dialysis, water treatment, energy storage in electrolysers and Redox systems and fuel cells (PEMFC) which have been recognized as promising new energy conversion technologies for clean power sources. Commercially available perfluorinated PEM, such as Nafion ${ }^{\circledR}$, are commonly used due to their excellent chemical and oxidative resistance as well as high proton conductivity, in the range of $0.1 \mathrm{~S} \mathrm{~cm}^{-1}$. However, their drawbacks are high cost and low operation temperature and have motivated researches on alternative proton conducting membranes to the perfluorinated membranes for high temperature PEMFC applications [1]. Many promising polymers are based on polyaromatic thermoplastics [1-4], such as poly(aryl ether ketone) (PAEK/PEEK), poly(ether sulfone) (PES), and polybenzimidazole (PBI) which have high chemical and thermal stability, low cost and an easier processing. The functionalization by sulfonation of these polymers leads to improved membrane properties (better wettability, higher water flux, better perm selectivity) and makes these sulfonated polymers good candidates for PEM materials. Examples include sulfonated polyether-ether ketones [5-7], sulfonated polyimides [8-10], sulfonated polybenzimidazole $[11,12]$,

\footnotetext{
* Corresponding author. Tel.: +331402724 01; fax: +3314027 2051 . E-mail address: cyrille.sollogoub@cnam.fr (C. Sollogoub).
}

sulfonated polystyrene $[13,14]$ and sulfonated polyether sulfone [15-19].

Polyethersulfone thermoplastics, widely used as membranes in dialysers, in ultra filtration and for reverse osmosis, exhibit a high resistance to hydrolysis. This resistance, combined with easiness for chemical modification and processing via casting, were decisive in selecting this polymer. In this paper, our choice was based on poly (bisphenol A sulfone) commercially available as UDEL P-3500 ${ }^{\circledR}$ from Solvay, which can be easily sulfonated as described in [19].

The proton conducting properties of PEMs for sulfonated aromatic polymers rely on proton solvation by water at high water activities: massive water uptake leads thus to a high proton conductivity of the hydrated membranes. The critical point of such membranes remains however the mechanical properties: dry membranes are brittle and hydrated membranes may exhibit a dramatic loss of mechanical properties.

As a strategy to improve proton conductivity and mechanical properties of the membranes, many approaches have been proposed. A first approach consists in incorporating in the membrane small inorganic particles, such as silica or zirconium phosphates [20]. A more classical approach is to develop sulfonated block copolymers, with the incorporation of soft units in stiff polymer backbones, which could provide the membrane with better flexibility. Many sulfonated block copolymers have been reported, such as sulfonated-fluorinated poly(arylene ether)s [21], sulfonated polysulfone-block-PVDF copolymers [22], poly(ether ether ketone)-block-sulfonated polybutadiene [23]. More recently, graft- 


\section{Nomenclature}

S-PESOS sulfonated polyethersulfone octylsulfonamide

S-PES sulfonated polyethersulfone

PEMFC proton exchange membrane fuel cell

IEC ionic exchange capacity

PEM proton exchange membrane

PES polyethersulfone

PBI polybenzimidazole

PEEK polyetheretherketone

NMR nuclear magnetic resonance

TGA thermo gravimetric analysis

DSC differential scanning calorimetry

DMA dynamical and thermomechanical analysis

MEA membrane electrode assembly

TMSCIS trimethylsilane chlorosulfonate

$W_{d r y} \quad$ dry weight

$W_{\text {Wet }}$ hydrated weight

$\tau \quad$ water uptake

$\sigma \quad$ ionic conductivity

$R_{\text {membrane }}$ resistance of the membrane

$S$ surface

$l \quad$ thickness of the membrane

$t_{\mathrm{H}+} \quad$ proton transport number

ing the sulfonic acid groups to specific chain segments in the polymer was shown to result in the formation of well-defined hydrophilic/hydrophobic phase-separated structures (like in the Nafion ${ }^{\circledR}$ membrane), inducing effective proton conduction [24,25]. Still, nowadays, none of these membranes could compete with Nafion membranes.

In this paper, a new simple strategy is proposed. It consists in keeping the polyaromatic skeleton of PES, and grafting pending chains of octylamine, which results in an increased flexibility. Our paper describes the results obtained by grafting octylamine groups at various proportions. The material has been characterized by ${ }^{1} \mathrm{H}$ RMN, TGA and DSC. Membranes have been cast and characterized by DMA, conductimetry, transport numbers and water swelling.

\section{Experimental part}

\subsection{Materials used}

Poly(ether sulfone) (UDEL P- $3500^{\circledR}$ ) was received from Solvay Polymer. That polymer has average molecular weights in the range between 20,000 and $50,000 \mathrm{~g} \mathrm{~mol}^{-1}$ and $\mathrm{Tg}$ close to $185^{\circ} \mathrm{C}$. It is soluble in various organic solvents such as methylene chloride, tetrahydrofuran, dimethylformamide and dimethylacetamide. It is stable up to $400^{\circ} \mathrm{C}$ in air.

Chlorotrimethyl silane, chlorosulfonic acid were received from Aldrich. Petroleum ether, dichloromethane, tetrahydrofuran and methanol were received from VWR, hydrochloric acid was received from LauryLab, phosphorous pentachloride was received from Fluka, octylamine and dimethylacetamide were received from Acros. All chemicals were used without further purification.

\subsection{Apparatus}

The NMR spectra were recorded an AC200 Bruker spectrometer $(200 \mathrm{MHz})$ at room temperature. The polymer sample $\left(40 \mathrm{mg} \mathrm{mL}^{-1}\right)$ were dissolved in DMSO-d6 $\left(\delta=2.49\right.$ ppm for ${ }^{1} \mathrm{H}$ NMR).

Differential scanning calorimetry (DSC) measurements are done using TA Instrument. A sample ( $3 \mathrm{mg}$ ) of polymer is put in the cell and the thermogram is registered between 20 and $225^{\circ} \mathrm{C}$ with a sweep rate of $5^{\circ} \mathrm{C} \mathrm{min}^{-1}$ under an argon flow of $40 \mathrm{~mL} \mathrm{~min}^{-1}$

The thermo gravimetric analysis (TGA) was carried out using a Perkin Elmer TGA 6. The approximately 5 and $10 \mathrm{mg}$ samples were first dried at $100{ }^{\circ} \mathrm{C}$ to remove any moisture and solvent for $8 \mathrm{~h}$, and then programmed from 30 to $400^{\circ} \mathrm{C}$ at a rate of $7^{\circ} \mathrm{C} \mathrm{min}^{-1}$ under a $40 \mathrm{~mL} \mathrm{~min}^{-1}$ nitrogen flow.

Electrical resistances were measured with a Hameg Instrument Conductimeter, LC-meter HM $8018,160 \mathrm{~Hz}$. The conductivities of proton exchange membranes were measured using a conductimetric clamp in $1 \mathrm{M} \mathrm{H}_{2} \mathrm{SO}_{4}$, as decribed in [26].

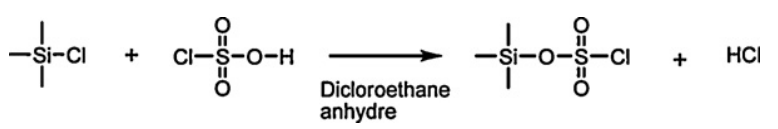

Fig. 1. Synthesis of trimethylsilyl chlorosulfonate (TMSCIS).

Hittorf cell: the cell is symmetrical, constituted by two glass compartments, each of $50 \mathrm{~mL}$, the membrane being clamped between them. The electrodes were made on platinized expanded titanium. The electrode surface is $4.15 \mathrm{~cm}^{2}$. The cell was filled with aqueous $\mathrm{H}_{2} \mathrm{SO}_{4} 1 \mathrm{M}$. Current densities were chosen as 100,75 and $40 \mathrm{~mA}$ during respectively 188,243 and $430 \mathrm{mn}$. The amount of proton transfer is close to $11 \mathrm{mmol}$, the initial proton content in every compartment being $100 \mathrm{mmol}$. Fig. 8 gives the principle of the method $[26,27]$.

Dynamic mechanical analysis (DMA) measurements were carried out with a TA Instruments DMA Q800 spectrometer working in the tensile mode. Membrane samples were cut with the following dimensions: length $11 \mathrm{~mm}$, width $5 \mathrm{~mm}$, thickness $0.2 \mathrm{~mm}$. Measurements were performed in isochronal conditions $(1 \mathrm{~Hz})$ and the temperature was varied between $0^{\circ} \mathrm{C}$ and $300^{\circ} \mathrm{C}$ at $3^{\circ} \mathrm{C} \mathrm{min}^{-1}$ under a flow of dry air of $50 \mathrm{~mL} \mathrm{~min}^{-1}$.

A membrane electrode assembly (MEA) was created using PaxiTech ${ }^{\circledR}$ electrodes (F-38130 Echirolles). The $64 \mathrm{~cm}^{2}$-membrane was sandwiched between an hydrogen electrode and an oxygen electrode, these two electrodes having a Pt-quantity of $0.5 \mathrm{mg} \mathrm{Pt} \mathrm{cm}^{-2}$. The fuel cell performances were recorded at ambient temperature and under atmospheric pressure $\left(P\left(\mathrm{H}_{2}\right)\right.$ and $P\left(\mathrm{O}_{2}\right)$ equal to $\left.1 \mathrm{~atm}\right)$.

\section{Polymer modification}

Sulfonation of poly(ether sulfone) was carried out in dichloromethane by stepwise addition of trimethylsilane chlorosulfonate (TMSClS) (Fig. 1). The process, similar to that described in [3], was carried under argon atmosphere and anhydrous conditions, gaseous $\mathrm{HCl}$ being evacuated promptly, in order to avoid any polymer chain breakage. TMSClS is a relatively mild but efficient reactant allowing a sulfonation of $1.3-\mathrm{SO}_{3} \mathrm{H}$ group per monomer unit. The mixture is stirred at $40^{\circ} \mathrm{C}$ during $24 \mathrm{~h}$ under argon bubbling. The resulting solution is then poured progressively into an ethanol solution of sodium ethanolate. The sodium salt of SPES SPES $\left(\mathrm{Na}^{+}\right)$precipitates. After filtration, the product is washed by ethanol, then by petroleum ether. It is dried during $72 \mathrm{~h}$ (yield $=95 \%$ ).

The acidic form of SPES SPES $\left(\mathrm{H}^{+}\right)$was obtained by ion exchange from SPES $\left(\mathrm{Na}^{+}\right)$with Amberlite IR-120, acid form at room temperature. Water is then evaporated and the product dried at $70^{\circ} \mathrm{C}$ under vacuum (yield $=88 \%$ ).

The chlorosulfonated form of S-PES $\left(-\mathrm{SO}_{2} \mathrm{Cl}\right.$ groups) was obtained from the sodium salt by reaction with phosphorous pentachloride under argon atmosphere. In a three necked flask, $50 \mathrm{~g}$ $\left(0.17 \mathrm{~mol}\right.$ of monomer unit) of S-PES $\left(\mathrm{Na}^{+}\right)$are put in anhydrous dichloroethane $(2 \mathrm{~L}) .10 \mathrm{~mL}$ of dimethylformamide are added to initiate the reaction. Phosphorous pentachloride $\left(\mathrm{PCl}_{5}\right)(0.36 \mathrm{~mol})$ $72.09 \mathrm{~g}$ is added portion wise (exothermic). Stirring of the orange solution is maintained during $12 \mathrm{~h}$, resulting $\mathrm{NaCl}$ is filtered off, and the limpid solution is poured in $6 \mathrm{~L}$ of methanol. The polymer precipitates, is filtered, washed with methanol and dried at $100^{\circ} \mathrm{C}$ under vacuum. The product is kept under argon atmosphere (yield = about 100\%).

Grafting of octylamine: five kinds of polymer grafted with octylamine have been prepared with various rates of grafting. Five identical solutions are prepared with $6 \mathrm{~g}(0.0104 \mathrm{~mol}$ of monomer unit) of SPES $(\mathrm{Cl})$ dissolved in $100 \mathrm{~mL}$ of tetrahydrofuran and kept under argon atmosphere at $60^{\circ} \mathrm{C}$. The following quantities of octylamine are added in every solution: first solution $0.52 \mathrm{~mL}(0.00314 \mathrm{~mol})$, second solution: $0.692 \mathrm{~mL}(0.00418 \mathrm{~mol})$, third solution: $0.87 \mathrm{~mL}(0.00526 \mathrm{~mol})$, fourth solution: $1.03 \mathrm{~mL}$ $(0.00628 \mathrm{~mol})$, fifth solution: $6.95 \mathrm{~mL}(0.0421 \mathrm{~mol})$ (Table 1$)$. The solutions are kept under stirring during $6 \mathrm{~h}$ at $60^{\circ} \mathrm{C}$. After cooling at room temperature, any solid is filtered off, and the solution poured in $500 \mathrm{~mL}$ of petroleum ether. The polymer is filtered out and washed with $\mathrm{HCl}(1 \mathrm{M})$ aqueous solution for hydrolysis of resid- 


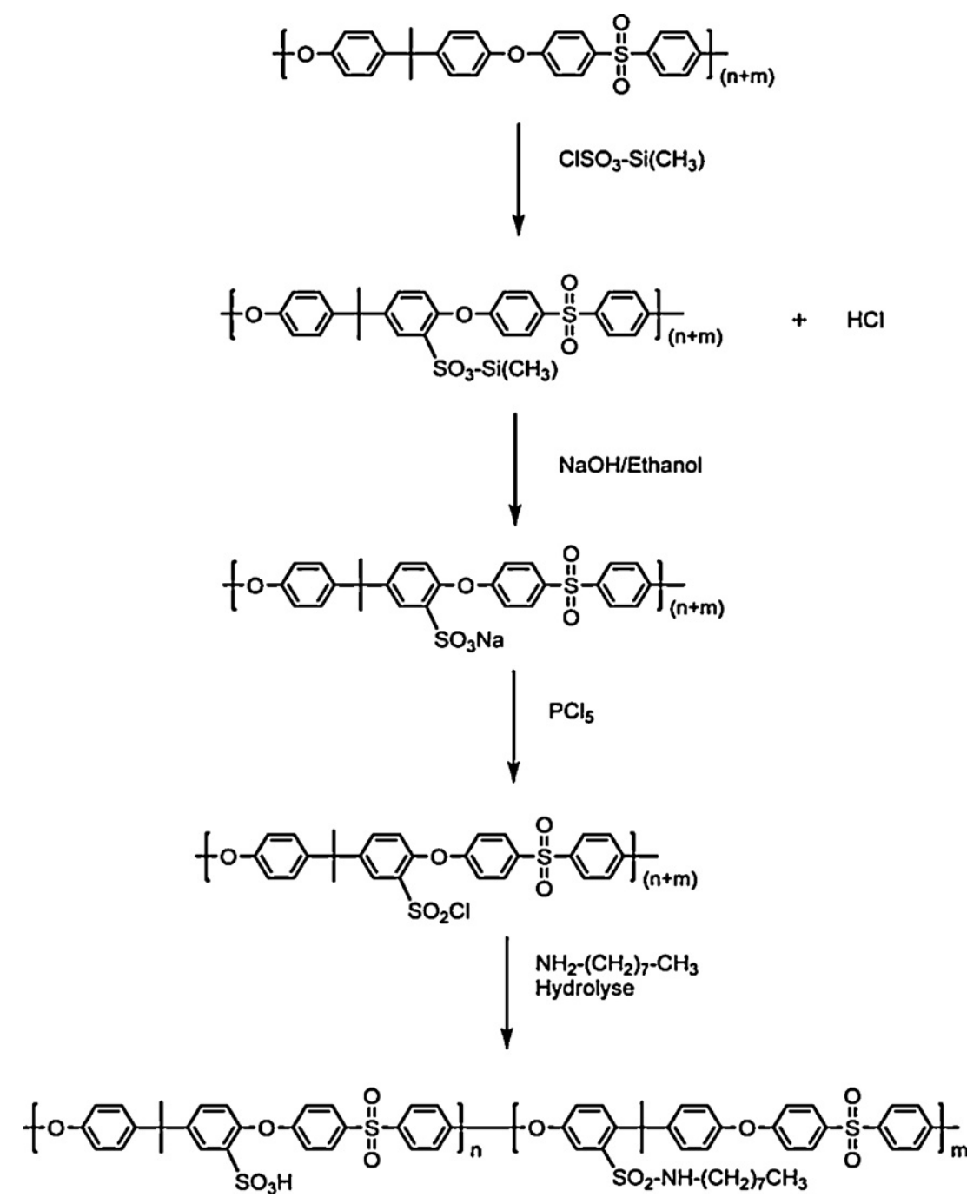

Fig. 2. Synthesis reaction of S-PESOS.

ual $\mathrm{SO}_{2} \mathrm{Cl}$ and elimination of unreacted amine. The polymer is then washed with water until the rinsing water keeps neutral. It is finally dried at $80^{\circ} \mathrm{C}$ for $12 \mathrm{~h}$ (Fig. 2). Yields are given in Table 1 .

The degree of sulfonation and the amount of octylamine grafted are confirmed by NMR (Figs. 3 and 4). Samples are dissolved in DMSO-d6. The peak at $1.65 \mathrm{ppm}$ is assigned to SPES methyl group, the peak at $0.8 \mathrm{ppm}$ to the octylamine methyl group. Ethanol (precipitating solvent) impurity may be detected at 1.2 and $3.7 \mathrm{ppm}$ (triplet and quadruplet). Signal at $1.2 \mathrm{ppm}$ is assigned to octylamine methylene groups $\left(-\mathrm{CH}_{2}\right)_{7}$, and signal at $2.6 \mathrm{ppm}$ is assigned to the octylamine methylene group vicinal to $(-\mathrm{NH}-)$. Integration of the different signals allows the determination of the grafted octylamine and sulfonic acid group amounts (Table 2). The amount of sulfonic

Table 1

Various degree of sulfonation of different membranes synthesized.

\begin{tabular}{lllc}
\hline & $\begin{array}{l}\text { Quantities of octylamine } \\
\text { (equivalent of mol) }\end{array}$ & $\begin{array}{l}\text { Ion exchange capacity } \\
\text { IEC }\left(\text { meq g }^{-1}\right)\end{array}$ & Yield (\%) \\
\hline S-PES & 0 & 2.38 & 98 \\
S-PESOS & 1.3 & 0 & 82 \\
S-PESOS & 0.3 & 1.91 & 85 \\
S-PESOS & 0.4 & 1.75 & 77 \\
S-PESOS & 0.5 & 1.58 & 98 \\
S-PESOS & 0.6 & 1.40 & 96 \\
Nafion ${ }^{\circledR} 117$ & - & 1.2 & - \\
\hline
\end{tabular}

acid is given by the ratio of signal A to signal B areas corresponding to aromatic protons (Fig. 3), using the following relation. The calculation is made on ungrafted SPES. This formula has been described and demonstrated in [19].

$$
\begin{aligned}
& R=\frac{\int B}{\int A}=\frac{17.474}{10}=1.7474 \\
& f=\frac{12-4 R}{2+R}=1.3 \mathrm{H}^{+} \mathrm{mol}^{-1} \\
& F=\frac{1000 \cdot f}{M+m \cdot f}=2.38 \mathrm{H}^{+} \mathrm{kg}^{-1}
\end{aligned}
$$

The results, given in Table 1, show that the non-grafted membranes give the maximal ion exchange capacity $\left(2.38 \mathrm{meq}^{-1}\right)$ and that the increase of grafted octylamine leads to a decrease of the degree of sulfonation.

\section{Preparation and characterization of membranes}

\subsection{Preparation of membranes}

Pristine or grafted SPES is dissolved in dimethylacetamide (DMA) at room temperature in order to have a solution $10 \%$ by 

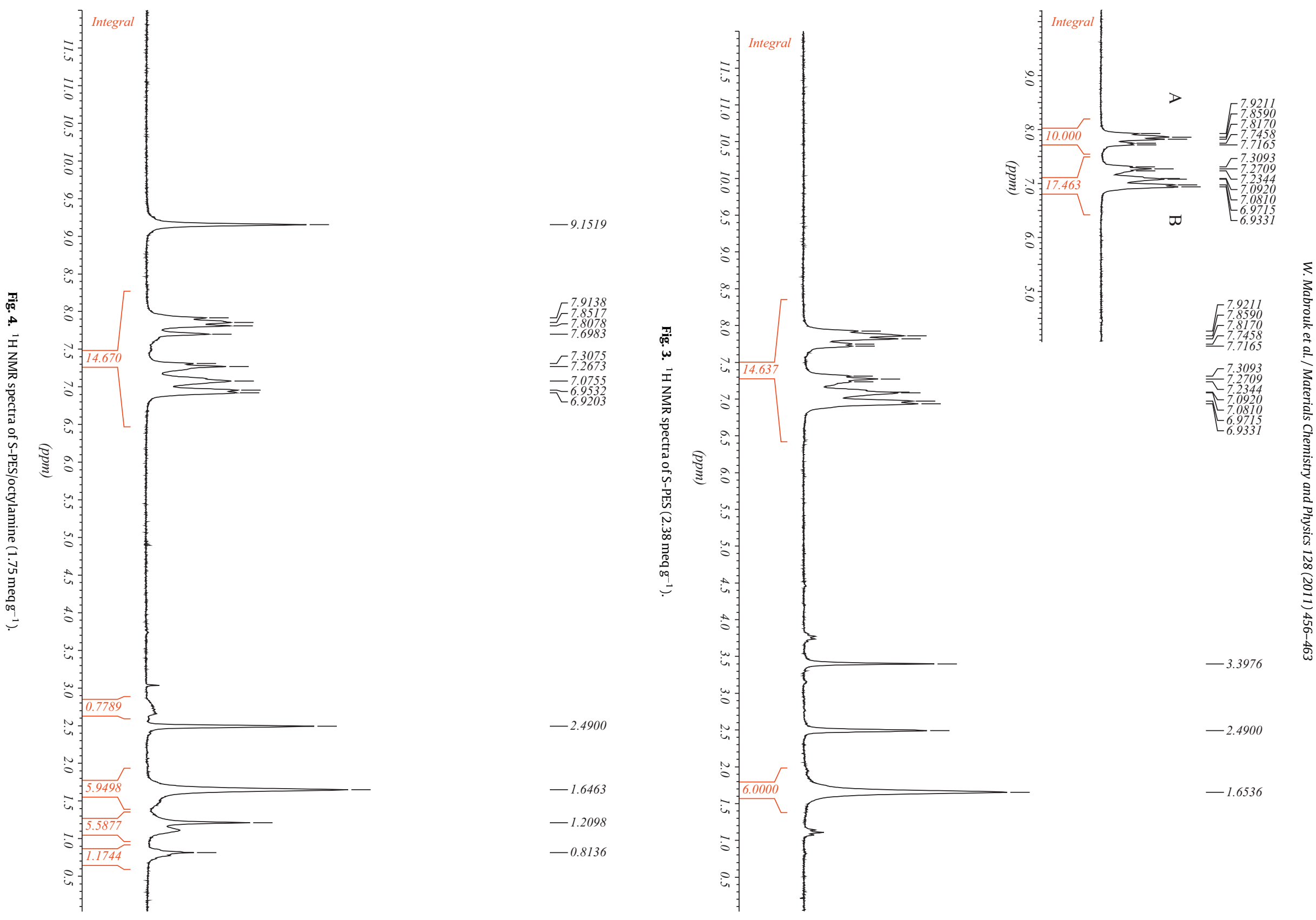

念 

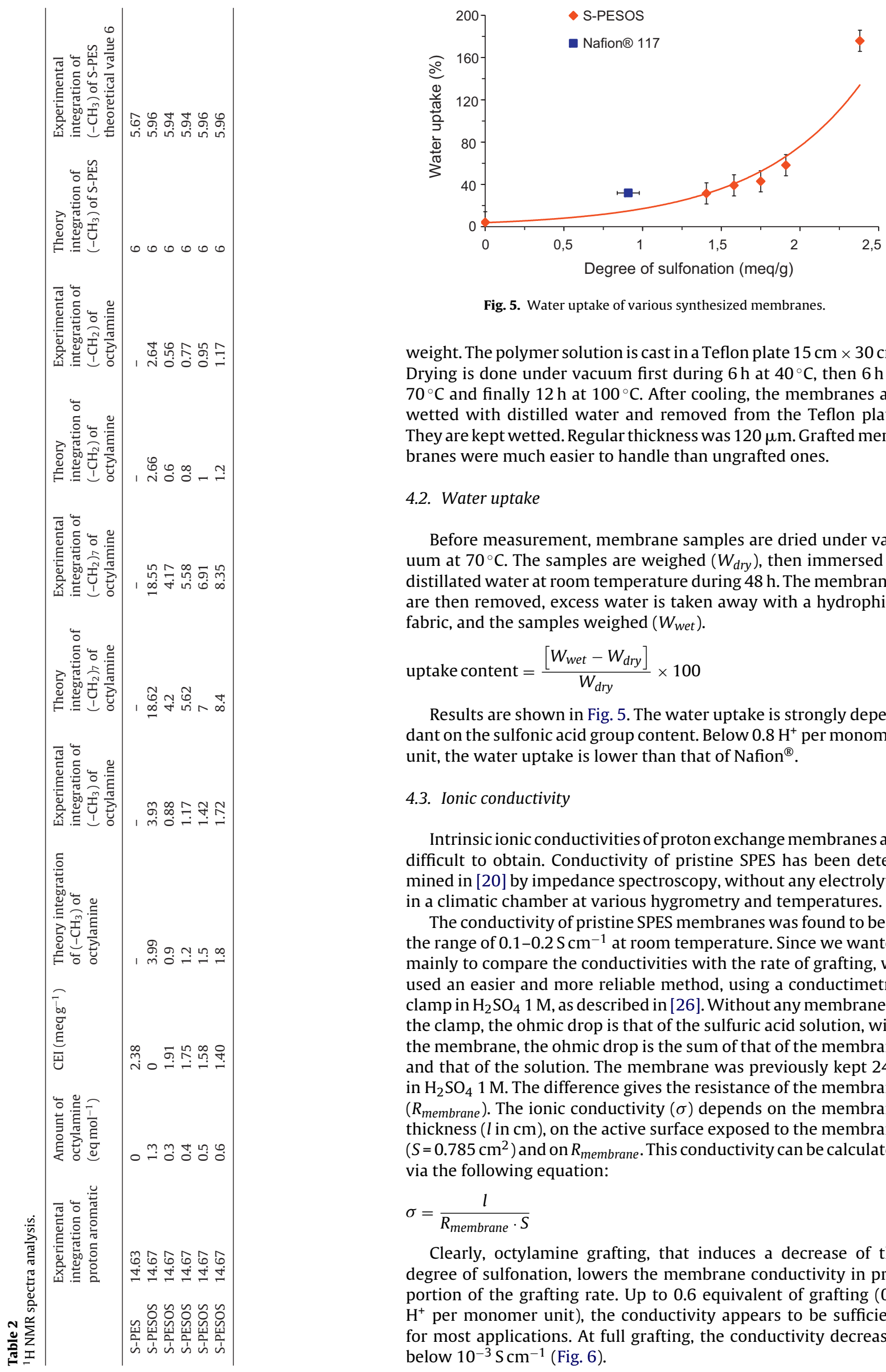

Fig. 5. Water uptake of various synthesized membranes.

weight. The polymer solution is cast in a Teflon plate $15 \mathrm{~cm} \times 30 \mathrm{~cm}$. Drying is done under vacuum first during $6 \mathrm{~h}$ at $40^{\circ} \mathrm{C}$, then $6 \mathrm{~h}$ at $70^{\circ} \mathrm{C}$ and finally $12 \mathrm{~h}$ at $100^{\circ} \mathrm{C}$. After cooling, the membranes are wetted with distilled water and removed from the Teflon plate. They are kept wetted. Regular thickness was $120 \mu \mathrm{m}$. Grafted membranes were much easier to handle than ungrafted ones.

\subsection{Water uptake}

Before measurement, membrane samples are dried under vacuum at $70^{\circ} \mathrm{C}$. The samples are weighed $\left(W_{d r y}\right)$, then immersed in distillated water at room temperature during $48 \mathrm{~h}$. The membranes are then removed, excess water is taken away with a hydrophilic fabric, and the samples weighed $\left(W_{\text {wet }}\right)$.

uptake content $=\frac{\left[W_{w e t}-W_{d r y}\right]}{W_{d r y}} \times 100$

Results are shown in Fig. 5. The water uptake is strongly dependant on the sulfonic acid group content. Below $0.8 \mathrm{H}^{+}$per monomer unit, the water uptake is lower than that of Nafion ${ }^{\circledR}$.

\subsection{Ionic conductivity}

Intrinsic ionic conductivities of proton exchange membranes are difficult to obtain. Conductivity of pristine SPES has been determined in [20] by impedance spectroscopy, without any electrolyte, in a climatic chamber at various hygrometry and temperatures.

The conductivity of pristine SPES membranes was found to be in the range of $0.1-0.2 \mathrm{~S} \mathrm{~cm}^{-1}$ at room temperature. Since we wanted mainly to compare the conductivities with the rate of grafting, we used an easier and more reliable method, using a conductimetric clamp in $\mathrm{H}_{2} \mathrm{SO}_{4} 1 \mathrm{M}$, as described in [26]. Without any membrane in the clamp, the ohmic drop is that of the sulfuric acid solution, with the membrane, the ohmic drop is the sum of that of the membrane and that of the solution. The membrane was previously kept $24 \mathrm{~h}$ in $\mathrm{H}_{2} \mathrm{SO}_{4} 1 \mathrm{M}$. The difference gives the resistance of the membrane ( $R_{\text {membrane }}$ ). The ionic conductivity $(\sigma)$ depends on the membrane thickness $(l$ in $\mathrm{cm}$ ), on the active surface exposed to the membrane ( $S=0.785 \mathrm{~cm}^{2}$ ) and on $R_{\text {membrane }}$. This conductivity can be calculated via the following equation:

$\sigma=\frac{l}{R_{\text {membrane }} \cdot S}$

Clearly, octylamine grafting, that induces a decrease of the degree of sulfonation, lowers the membrane conductivity in proportion of the grafting rate. Up to 0.6 equivalent of grafting ( 0.7 $\mathrm{H}^{+}$per monomer unit), the conductivity appears to be sufficient for most applications. At full grafting, the conductivity decreases below $10^{-3} \mathrm{Scm}^{-1}$ (Fig. 6). 


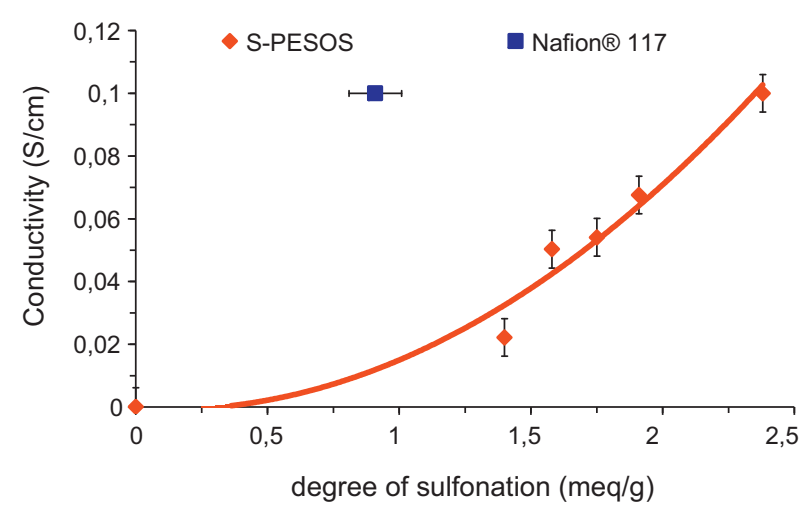

Fig. 6. Ionic conductivity of various synthetized membranes.

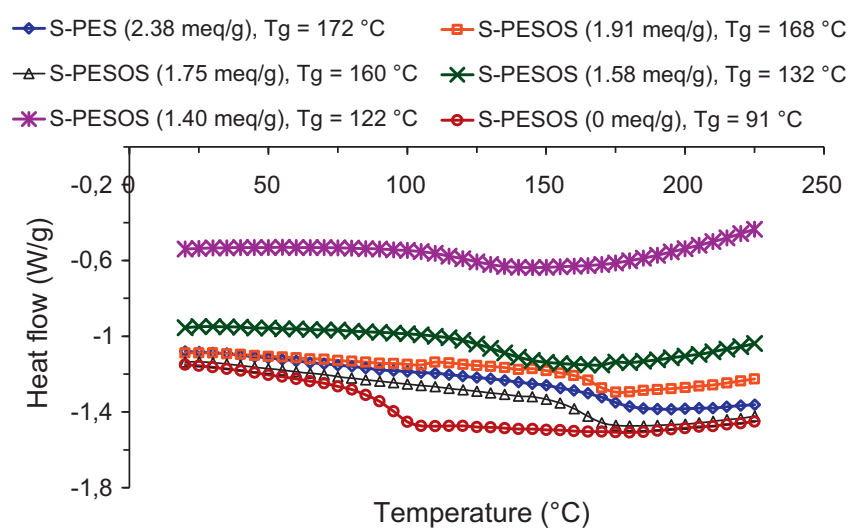

Fig. 7. DSC curves of polymers synthesized.

\subsection{Proton transport number (Hittorf's cell)}

When the transport number of proton equals to one, the amount of protons in every compartment should not change, proton production at the anode compensates the proton transfer through the membrane, itself compensating the proton reduction to dihydrogen at the cathode. The proton concentration may vary slightly in each compartment, because some water is electrolysed, proton is migrating with solvating water, and some water evaporation may occur. Accurate measurements are difficult and fair reliability is obtained by assessment of the proton content

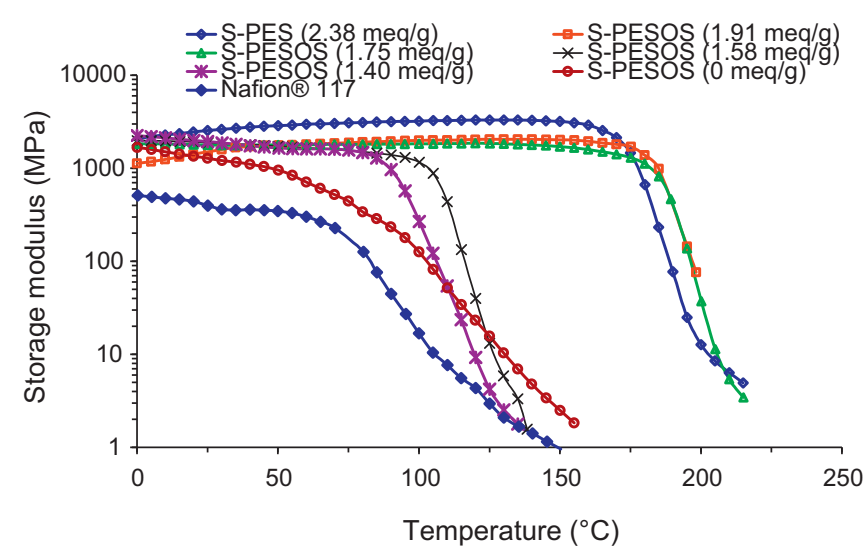

Fig. 9. DMA study of various synthesized membranes.

in both compartments, $Q_{0}$ at the beginning, $Q_{f}$ at the end of the electrolysis. Proton selectivity may also depend on the current density, but our method cannot ascertain if some water dissociation into proton and hydroxyl anion occurs at the anodic surface of the membrane. Determination of $Q_{0}^{a}, Q_{0}^{c}$ and $Q_{f}^{a}, Q_{f}^{c}$ in the anodic (respectively cathodic) compartment determines the anodic (respectively cathodic) initial and final transport number computed from the following formula:

$t_{a}^{\left(H^{+}\right)}=\frac{\left(Q_{0}^{a}-Q_{f}^{a}\right) F}{I t}+1 \quad t_{c}^{\left(H^{+}\right)}=\frac{\left(Q_{f}^{c}-Q_{0}^{c}\right) F}{I t}+1$

Results are given in Table 3. Within experimental errors, the membranes are selectively proton conducting whatever the amount of octylamine grafting.

\subsection{Dynamical and thermomechanical analysis (DMA)}

The different membranes display similar typical behaviour: in the glassy state $\left(T<100^{\circ} \mathrm{C}\right)$, the tensile storage modulus $E^{\prime}$ remains roughly constant and very high, which explains the high embrittlement of the membranes. Then around a temperature comprised between $100^{\circ} \mathrm{C}$ and $200^{\circ} \mathrm{C}$, we observe a modulus drop, associated with the glass transition. It appears that the glass transition temperature, at which occurs this drop, depends on the rate of octylamine grafting. Results are shown in Fig. 9.

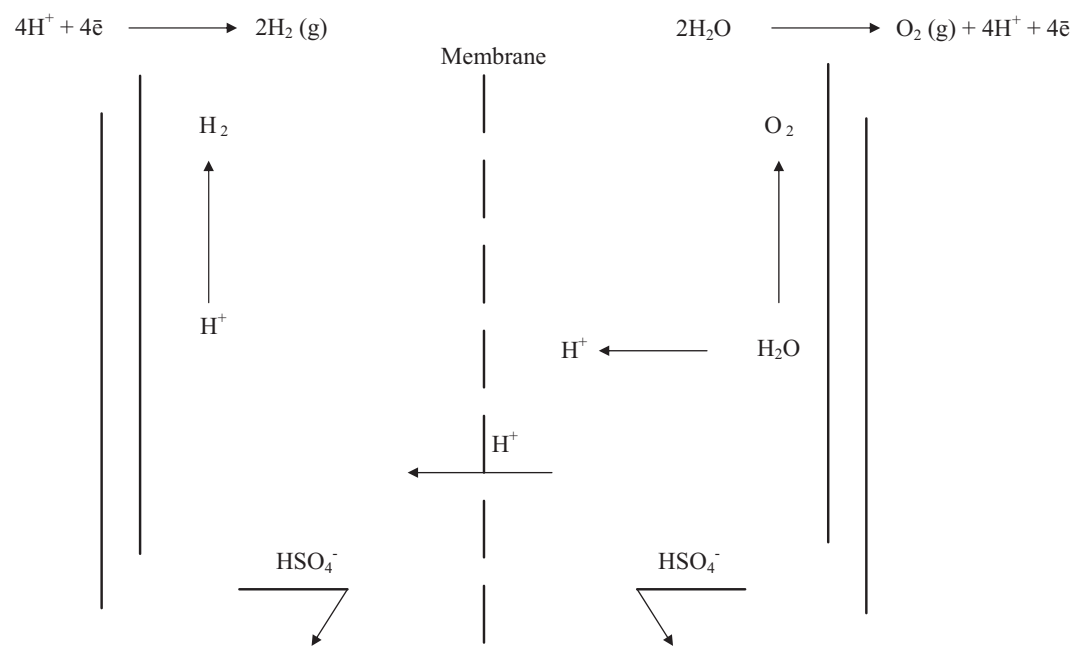

Fig. 8. Principle of transport numbers. 
Table 3

Transport numbers of all synthesized membranes.

\begin{tabular}{|c|c|c|c|c|c|}
\hline & Surface $\left(\mathrm{cm}^{2}\right)$ & Time (mn) & Current intensity $(\mathrm{mA})$ & $t^{+}$cathodic & $t^{+}$anodic \\
\hline S-PES (2.38 meq g $\left.^{-1}\right)$ & 4.15 & 188 & 100 & 0.99 & 0.98 \\
\hline S-PES $\left(2.38\right.$ meq g $\left.^{-1}\right)$ & 4.15 & 243 & 70 & 0.99 & 0.99 \\
\hline S-PES (2.38 meq g $\left.^{-1}\right)$ & 4.15 & 430 & 40 & 0.99 & 0.98 \\
\hline S-PESOS (1.91 meq g $\left.{ }^{-1}\right)$ & 4.15 & 188 & 100 & 0.98 & 0.98 \\
\hline S-PESOS (1.91 meq g $\left.{ }^{-1}\right)$ & 4.15 & 243 & 70 & 0.99 & 0.99 \\
\hline S-PESOS (1.91 meq g $\left.{ }^{-1}\right)$ & 4.15 & 430 & 40 & 0.99 & 0.99 \\
\hline S-PESOS ( $\left.1.75 \mathrm{meqg}^{-1}\right)$ & 4.15 & 188 & 100 & 0.98 & 0.97 \\
\hline S-PESOS (1.75 meq g $\left.{ }^{-1}\right)$ & 4.15 & 243 & 70 & 0.96 & 0.92 \\
\hline S-PESOS ( $\left.1.75 \mathrm{meqg}^{-1}\right)$ & 4.15 & 430 & 40 & 0.99 & 0.99 \\
\hline S-PESOS ( 1.58 meq g $\left.^{-1}\right)$ & 4.15 & 188 & 100 & 0.99 & 0.97 \\
\hline S-PESOS (1.58 meq g $\left.{ }^{-1}\right)$ & 4.15 & 243 & 70 & 0.99 & 0.97 \\
\hline S-PESOS ( $1.58 \mathrm{meq} \mathrm{g}^{-1}$ ) & 4.15 & 430 & 40 & 0.99 & 0.99 \\
\hline S-PESOS ( $\left.1.40 \mathrm{meq} \mathrm{g}^{-1}\right)$ & 4.15 & 188 & 100 & 0.99 & 0.98 \\
\hline S-PESOS ( $1.40 \mathrm{meq} \mathrm{g}^{-1}$ ) & 4.15 & 243 & 70 & 0.99 & 0.99 \\
\hline S-PESOS $\left(1.40 \mathrm{meq} \mathrm{g}^{-1}\right)$ & 4.15 & 430 & 40 & 0.99 & 0.98 \\
\hline Nafion $^{\circledR} 117$ & 4.15 & 188 & 100 & 0.99 & 1.00 \\
\hline Nafion $^{\circledR} 117$ & 4.15 & 243 & 70 & 1.00 & 1.00 \\
\hline Nafion $^{\circledR} 117$ & 4.15 & 430 & 40 & 0.99 & 0.99 \\
\hline
\end{tabular}

The effect of the octylamine grafting is in accordance with that observed in DSC: it tends to lower the glass transition temperature and thus to reduce the brittleness of the membrane. For the SPES octylamine $\left(0.8 \mathrm{H}^{+} \mathrm{mol}^{-1}\right)$ and $\left(0.7 \mathrm{H}^{+} \mathrm{mol}^{-1}\right)$ membranes, the glass transition temperature is comprised between 120 and $135^{\circ} \mathrm{C}$, which is quite similar to Nafion $\mathrm{Tg}$ (Fig 7).

\subsection{Membrane-electrode assembly}

Assemblies were carried out with the different membranes and the fuel cell performances, recorded at ambient temperature and under atmospheric pressure, are shown Fig. 11 and are compared to the Nafion 117. It is noteworthy that no measurement was possible with the non-grafted membrane $\left(2.38 \mathrm{meq}^{-1}\right)$, since the membrane was too brittle and broke in the MEA.

\section{Discussion}

Literature describing the use of sulfonated polyaromatics is rather scarce, although a large number of papers describes the formation and properties of pure or modified membranes such as sulfonated polyether ketones or polyether sulfones. Among polyether sulfones prepared from bisphenol A, UDEL P- $3500^{\circledR}$ is especially interesting because the monomer unit presents two benzene rings where sulfonation can occur. Sulfonation is easily performed up to 1.3 sulfonic group per monomer unit. Such an amount of sulfonic groups is usually unnecessary for most applications, especially fuel cells, because the polymer becomes

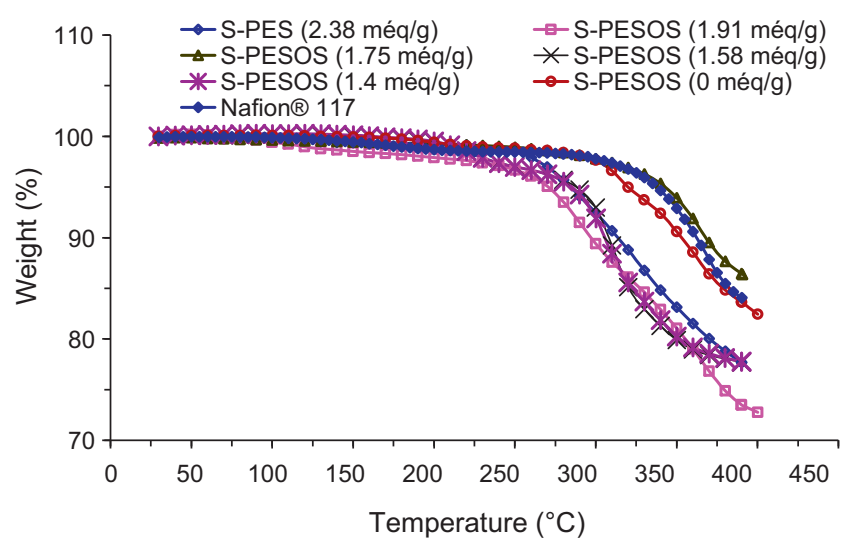

Fig. 10. Thermal stability of all polymers synthesis. water-soluble at high temperature $\left(>80^{\circ} \mathrm{C}\right)$ when the sulfonic contents increase above 0.8 groups per monomer unit. But above this amount, excess sulfonic groups may be used for modifying the polymer, enhancing its softness and lowering its solubility. We designed a process for obtaining a polymeric backbone with 1.3 $\left(-\mathrm{SO}_{2} \mathrm{Cl}\right)$ group per monomer unit, without any reticulation by $\left(-\mathrm{SO}_{2}-\right)$ groups bridging the chains. This is a very important result, since $\left(-\mathrm{SO}_{2} \mathrm{Cl}\right)$ groups are very reactive and can be used at will for grafting different kinds of substrates on the chain.

We present here the results obtained with octylamine. That substrate is common, easy to handle, the $-\mathrm{NH}_{2}$ group is reactive, the aliphatic chain is flexible (polyethylene has a $\mathrm{Tg}$ below $-30^{\circ} \mathrm{C}$ ). The resulting sulfonamide group is resistant to hydrolysis and oxidation.

The grafting of octylamine is quantitative, and the rate of grafting can be chosen at will, as demonstrated by NMR analysis (Table 3). The resulting material is thermally stable as demonstrated by DSC and TGA experiments (Figs. 7 and 10).

Pristine SPES $\left(2.4\right.$ meq $\left.\mathrm{g}^{-1}, 1.3 \mathrm{H}^{+} \mathrm{mol}^{-1}\right)$ shows a glass transition temperature $(\mathrm{Tg})$ of $172^{\circ} \mathrm{C}$. Glass transition temperatures of octylamine grafted SPES are shifted to lower temperatures, up to $92^{\circ} \mathrm{C}$ for the fully grafted SPES. The results of glass transition temperature collected by DSC are in agreement with those obtained by DMA.

The glass transition temperatures are lowered if sufficient amount of octylamine is grafted. The resulting material is insoluble in water and in aliphatic hydrocarbons, but can be dissolved

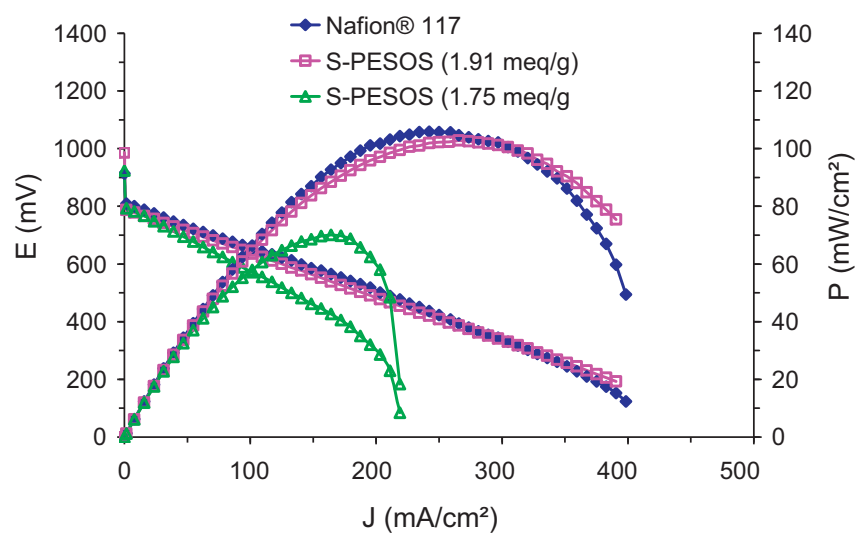

Fig. 11. Fuel cell performances, Paxitech ${ }^{\circledR} \mathrm{S}=64 \mathrm{~cm}^{2}, \mathrm{H}_{2}$ and $\mathrm{O}_{2}$ flow rates $=324$ and $517 \mathrm{~mL} \mathrm{~min}^{-1}$, respectively. 
in solvents such as DMSO, dimethylacetamide or other polar aprotic solvents. Membranes can be cast from these solutions. They appear to be homogeneous, transparent, much less brittle than the ungrafted membranes and flexible when wet. They are easy to handle. Thermomechanical dynamic analysis on dry membranes confirms the properties observed by DSC (Fig. 7).

All acidic polymers synthesized show two weight loss stages. The first weight loss at around $100^{\circ} \mathrm{C}$ is related to the adsorption of water bonded to the sulfonic groups. The second weight loss is assigned to the decomposition of sulfonic groups. A comparison between the TGA of SPES ( 2.4 meq $\left.^{-1}\right)$ and all SPESOS synthesized show no differences in the range of fuel cell application. The decomposition of sulfonic groups of acidic SPES $\left(2.4 \mathrm{meq}^{-1}\right)$ started at $250^{\circ} \mathrm{C}$ and the decomposition of sulfonamide groups of SPESOS $\left(0 \mathrm{meq} \mathrm{g}^{-1}\right)$ started at $300^{\circ} \mathrm{C}$. Hence, the sulfonic groups decomposed faster than the sulfonamide groups.

In the SPESOS membranes $\left(1.91,1.75\right.$ and 1.40 meqg $\left.^{-1}\right)$ the two steps of decomposition (sulfonic and sulfonamide) could be noticed. Results are shown in Fig. 10.

Dynamical and thermomechanical behaviour of the samples of membranes have been compared. Their storage moduli behave similarly upon variation of temperature. They are rigid at low temperature and flexible near the glass transition temperature. Thermomechanical properties are dependant upon the rate of octylamine grafting, as shown in Fig. 9. Softening occurs when the rate of grafting is higher than 0.4 octylamine per monomer unit.

Water swelling is not excessive $(<50 \%$ per weight) when the grafting is sufficient ( $\geq 0.3$ octylamine per monomer unit). Unless the membrane is totally grafted, the conductivity is sufficient for most possible applications: fuel cells, electrolysers, electro dialysis, etc.

This is confirmed by the first preliminary results obtained in fuel cells (Fig. 11). Membranes having similar conductivities to the Nafion 117 membrane (Fig. 6) exhibit similar performances in fuel cells. For example, the power density of these cells with SPESOS membranes ( $1.91 \mathrm{meq}^{-1}$ ) reaches nearly $110 \mathrm{~mW} \mathrm{~cm}^{-2}$ at room temperature, which is similar to the fuel cells containing Nafion 117. It is quite encouraging to reach the same performances as the Nafion 117 but with a much less expensive membrane. Further measurements at $80^{\circ} \mathrm{C}$ are in progress.

The values of conductivity are high and do not represent the intrinsic conductivity of membranes SPESOS without sulfuric acid. Normally, the results of conductivity should be obtained by impedancemetry at relative humidity and temperatures controlled [28]. But our figures give a good idea of the trend of conductivity as a function of grafting grade, as compared to Nafion 117 in the same conditions (Fig. 6). It is clear that softness is obtained at the detriment of conductivity. Experiments are under progress for improving the conductivity of SPESOS membranes without loosing the softness.

Furthermore the different membranes were proved to be ion selective with proton transfer numbers close to one. This result will be extended to other ions. Much more work has still to be done for obtaining the scope and limitations of that kind of materials, but our preliminary experiments demonstrate that sulfonated polyaromatics afford very interesting materials with certainly a large scope of possible modifications.

\section{Conclusion}

Sulfonated poly(ether sulfone), with different rate of sulfonation has been prepared as described in [19]. But the SPES with $1.3 \mathrm{SO}_{3} \mathrm{H}$ per monomer unit $\left(2.4 \mathrm{meq}^{-1}\right)$ is a completely new synthesis. A process has been designed for the quantitative transformation of $-\mathrm{SO}_{3} \mathrm{H}$ groups into $\mathrm{SO}_{2} \mathrm{Cl}$ groups, without any reticulation by $-\mathrm{SO}_{2}-$ bridges. From that material, octylamine has been grafted on the PESS backbone at various degrees of grafting. ${ }^{1} \mathrm{H}$ NMR confirms the quantitative grafting of octylamine. After hydrolysis the material contains sulfonamide and sulfonic acid groups in predetermined proportions. DSC measurement shows a lowering of the glass transition temperature when the amount of octylsulfonamide is higher than 0.3 groups per monomer unit. The resulting material has been cast in membranes. The membranes show a smooth variation of ionic conductivity and water uptake in relation with the amount of grafted octylamine. In $\mathrm{H}_{2} \mathrm{SO}_{4}$ solutions the selectivity of the membrane is very high for proton transport. DMA determinations show that the softness of the membranes has been increased by octylamine grafting. The TGA curves schow a good stability of SPESOS in the temperature range for fuel cell application. Such membranes may be used for the usual applications of proton conducting polymer membranes, for example fuel cells. Grafting of other substrates than octylamine is currently under progress.

\section{Acknowledgments}

The authors thank the French ANRT (Agence Nationale pour la Recherche et la Technologie) for the support of one of them (W. Mabrouk).

The authors acknowledge for the help of C. Iojoiu, from Laboratoire d'Electrochimie et de Physico Chimie des Matériaux et des Interfaces, LEPMI, Saint Martin d'Hères, 38402 Grenoble, France, for interesting discussions.

\section{References}

[1] O. Savadogo, J. Power Sources 127 (2004) 135

[2] K.D. Kreuer, J. Membr. Sci. 185 (2001) 29.

[3] J. Kerres, J. Membr. Sci. 185 (2001) 3.

[4] M. Rikukawa, K. Sanui, Prog. Polym. Sci. 25 (2000) 1463.

[5] S.M.J. Zaidi, S.D. Mikhailenko, G.P. Robertson, M.D. Guiver, S. Kaliaguine, J. Membr. Sci. 173 (2000) 17.

[6] P. Xing, G.P. Robertson, M.D. Guiver, S.D. Mikhailenko, K. Wang, S. Kaliaguine, J. Membr. Sci. 229 (2004) 95.

[7] D. Daoust, J. Devaux, P. Godard, Polym. Int. 50 (2001) 925.

[8] C. Genies, R. Mercier, B. Sillion, N. Cornet, G. Gebel, M. Pineri, Polymer 42 (2001) 359.

[9] J. Fang, X. Guo, S. Harada, T. Watari, K. Tanaka, H. Kita, K. Okamoto, Macromolecules 35 (2002) 9022.

[10] W. Essafi, G. Gebel, R. Mercier, Macromolecules 37 (2004) 1431.

[11] J.A. Asensio, S. Borrós, P. Gómez-Romero, J. Polym. Sci. Part A: Polym. Chem. 40 (2002) 3703.

[12] D.J. Jones, J. Rozière, J. Membr. Sci. 185 (2001) 41.

[13] F.N. Büchi, B. Gupta, O. Haas, G.G. Scherer, Electrochim. Acta 40 (1995) 345

[14] J. Yu, B. Yi, D. Xing, F. Liu, Z. Shao, Y. Fu, H. Zhang, Phys. Chem. Chem. Phys. 5 (2003) 611.

[15] J. Kerres, W. Cui, S. Reichle, J. Polym. Sci. Part A: Polym. Chem. 34 (1996) 2421.

[16] D. Poppe, H. Frey, K.D. Kreuer, A. Heinzel, R. Mulhaupt, Macromolecules 35 (2002) 7936

[17] P. Genova-Dimitrova, B. Baradie, D. Foscallo, C. Poinsignon, J.Y. Sanchez, J. Membr. Sci. 185 (2001) 59.

[18] Y.S. Kim, B. Einsla, M. Sankir, W. Harrison, B.S. Pivovar, Polymer 47 (2006) 4026

[19] C. Iojoiu, P. Genova-Dimitrova, M. Maréchal, J.-Y. Sanchez, Electrochim. Acta 51 (2006) 4789.

[20] B. Bonnet, D. Jones, J. Roziere, L. Tchicaya, G. Alberti, M. Casciola, L. Massinelli, B. Bauer, A. Peraio, E. Ramunni, J. New Mater. Electrochem. Syst. 3 (2000) 87

[21] H. Ghassemi, J.E. McGrath, T.A. Zawodzinski Jr., Polymer 47 (2006) 4132.

[22] Y. Yang, Z. Shi, S. Holdcroft, Eur. Polym. J. 40 (2004) 531.

[23] Y. Zhao, J. Yin, Eur. Polym. J. 46 (2010) 592.

[24] K. Matsumoto, T. Higashihara, M. Ueda, Macromolecules 42 (2009) 1161.

[25] E.P. Jutemar, P. Jannasch, J. Membr. Sci. 351 (2010) 87.

[26] E. Agel, J. Bouet, J.F. Fauvarque, J. Power Sources 101 (2001) 267.

[27] M. Kameche, F. Xu, C. Innocent, G. Pourcelly, Z. Derriche, Sep. Purif. Technol. 52 (2007) 497.

[28] M.J. Sumner, W.L. Harrison, R.M. Weyers, Y.S. Kim, J.E. McGrath, J.S. Riffle, A. Brink, M.H. Brink, J. Membr. Sci. 239 (2004) 199. 